\title{
Determinants of Foreign Direct Investment: An Application on MSCI Emerging Markets Index
}

\author{
Sinan AYTEKIN \\ Associate Professor, Faculty of Economics and Administrative Sciences, Balıkesir University, Ballkesir, Turkey
}

\begin{abstract}
The aim of this study is to examine the determinants of foreign direct investment (FDI) in emerging countries for the period 2002-2014. As well as some economic variables, the impact of country level governance quality on FDI is investigated. The country level governance quality is measured by world bank governance indicators which are voice and accountability, political stability and absence of voilence, governance effectiveness, regulatory quality, rule of law and control of corruption. The hypothesis is tested by using Generalized Moment of Methods, a relation between governance quality and FDI is found. According to the regression results, a positive relationship is found between FDI and voice and accountability, regulatory quality, rule of law and control of corruption. As for other economic variables, it is determined that GDP growth and lagged value of FDI have a positive effect on FDI, and unemployment rate and population growth have negative effects on FDI.
\end{abstract}

Keywords: Foreign Direct Investment, Generalized Moment of Methods, MSCI Emerging Markets Index.

\section{Introduction}

Today, both businesses and countries have come across with changing conditions as the competitiveness conditions increase. As an extension of this condition, traditional factors of production such as capital and labor have fallen apart from being the key determinants of competition (Jeong, 2014, p. 476). In this direction, countries that want to gain a stable growth graph have started to head for resources that are less liquid but which provide added value to the economy in order to eliminate increasing risks of portfolio investments as environment of confidence is provided in the emerging markets especially in 1990's (Kar and Tatlısöz, 2008, p. 439). Foreign Direct Investments (FDI) that contain both advantages and disadvantages in itself from the perspectives of investor and investee countries have become one of the major factors for the economic stability of emerging countries at this point and countries have been in competition with each other in order to attract FDI by implementing different policies (Özcan and Arı, 2010, p. 66). Because investment amounts which can also be defined as the national savings of a country are one of the major factors of economic growth (Bekana, 2016, p. 141, Özçalık and Gibson, 2016, p. 58).

As the concept of FDI can be defined in different ways, it is expressed as the aim of affording advantage by settled individuals or institutional structures who carry on a business in a foreign country in the definition made by the OECD (Organisation for Economic Cooperation and Development). Here, the investor country increases the employment by carrying on permanent business with its capital, knowledge, and technology (Malhotra, Russow and Singh, 2014, p. 131).

FDI goes towards developed countries mostly since they don't have infrastructure problems and don't need certain additional investment. One reason for this is that development indicators such as rule of law, fight against corruption, political stability as well as economic stability that can be counted as institutional factors are fulfilled beyond dispute in these countries (SETA, 2011, p. 8). Therefore, the countries which will compete for taking a share from FDI are the emerging ones. Starting from this point of view, in this study, it is investigated to which economic and institutional factor should the countries that are involved in Morgan Stanley Capital International Emerging Markets (MSCI EM) Index focus on. When looking at the literature, there are studies that tried to determine the determinants of FDI for the groups of countries that are included in the specifications such as OECD countries or BRIC countries altogether as well as on an individual basis. In this study, as distinct from others, it is tried to determine the determinants of FDI of 22 countries data of which are available and which fall into MSCI Emerging Markets Index that consists of 23 countries with economic and institutional variables.

\section{Literature Review}

Nonnemberg and Mendonça (2004) stated in their study that although the theoric studies about determinants of FDI go back to Adam Smith, Stuart Mill and Torrens, in fact Ohlin (1933) was the first to make a study that deals with the topic in today's context. As a continuation of this study, determinants of FDI are generally evaluated under two titles. While economic factors are accepted as determinants of FDI in some studies (Mahalakshmi, Thiyagarajan and Naresh, 2015, Nonnemberg and Mendonça, 2004), when we approach 
these days we see that institutional variables are also added to these factors (Huang et al., 2016, Yean, Yen Nee and Jia Yi, 2015, Botello and Davilla, 2015). In Table 1, some studies are summarized that are carried for different a country (or countries) and in which both economic and institutional variables are used.

Table 1: Studies That Examine The Determinants of Foreign Direct Investment

\begin{tabular}{|c|c|c|c|c|c|}
\hline Year & Author(s) & Purpose/Variables & Method & Scope & Conclusion \\
\hline 2004 & 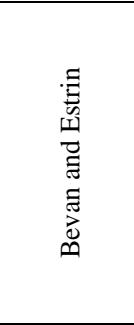 & $\begin{array}{l}\text { They analyzed the variables unit } \\
\text { cost of labor, the distance } \\
\text { between the capitals of the } \\
\text { countries, trade openness, risk, } \\
\text { annual bond yield, GDP and } \\
\text { market size in order to determine } \\
\text { the determinants of FDI. }\end{array}$ & 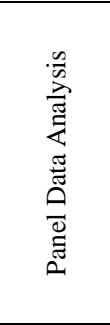 & $\begin{array}{l}\text { Data of Western } \\
\text { countries, } \\
\text { particularly } \\
\text { Central and } \\
\text { Eastern European } \\
\text { countries of } \\
\text { transition, } \\
\text { between the years } \\
\text { 1994-2000 are } \\
\text { analyzed. }\end{array}$ & $\begin{array}{l}\text { They determined the most important } \\
\text { factors as market size, unit cost of } \\
\text { labor and distance. Among them, they } \\
\text { determined a negative relationship } \\
\text { between market sizes of the country of } \\
\text { origin and the source country. It is } \\
\text { mention that the risk of the host } \\
\text { country is not an important } \\
\text { determinant. }\end{array}$ \\
\hline 2010 & 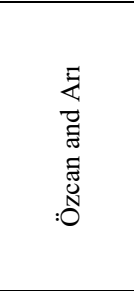 & $\begin{array}{l}\text { They used the variables rate of } \\
\text { current account deficit in GDP, } \\
\text { infrastructure level, trade } \\
\text { openness, inflation rate, GDP } \\
\text { growth rate and the rate FDI in } \\
\text { GDP. }\end{array}$ & $\sum_{\circlearrowright}$ & $\begin{array}{l}\text { Data of } 27 \text { OECD } \\
\text { countries between } \\
\text { the years 1994- } \\
2006 \quad \text { are } \\
\text { analyzed. }\end{array}$ & $\begin{array}{l}\text { They specified that FDI is affected by } \\
\text { GDP growth rate, the states that are in } \\
\text { good condition in terms of } \\
\text { infrastructure remain ahead of the FDI } \\
\text { game, the inflation rate has a positive } \\
\text { relation with FDI although less } \\
\text { effective in comparison with other } \\
\text { variables and trade openness has a } \\
\text { negative effect with FDI. }\end{array}$ \\
\hline 2015 & 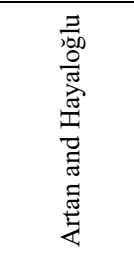 & $\begin{array}{l}\text { They used the variables } \\
\text { exchange rate, trade openness, } \\
\text { population growth, schooling } \\
\text { rate and political risk index that } \\
\text { have } 12 \text { subcomponents in order } \\
\text { to determine both economic and } \\
\text { institutional determinants of } \\
\text { FDI. }\end{array}$ & 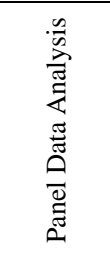 & $\begin{array}{l}\text { Data of } 29 \text { OECD } \\
\text { countries between } \\
\text { the years } 1990- \\
2012 \text { are } \\
\text { examined. }\end{array}$ & $\begin{array}{l}\text { They precipitated that institutional } \\
\text { factors are more effective than } \\
\text { economic factors among FDI } \\
\text { determinants that constitute political } \\
\text { risk index. }\end{array}$ \\
\hline 2002 & 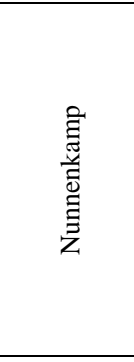 & $\begin{array}{l}\text { They included the variables } \\
\text { population, GDP, administrative } \\
\text { impediments, barriers to market } \\
\text { entry, risk factors, } \\
\text { complementary factors of } \\
\text { production, education period, } \\
\text { cost factors, barriers to foreign } \\
\text { trade, restrictions after entry and } \\
\text { regulations about the technology } \\
\text { to the analysis in order to specify } \\
\text { the determinants of FDI. }\end{array}$ & 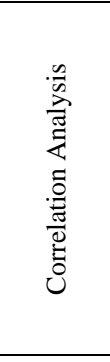 & $\begin{array}{l}\text { Data from } 28 \\
\text { developing } \\
\text { countries between } \\
\text { the years1987- } \\
2000 \text { are } \\
\text { examined. }\end{array}$ & $\begin{array}{l}\text { He precipitated that traditional } \\
\text { determinants related to the market are } \\
\text { still the most dominant factors that } \\
\text { affect FDI distribution and that as for } \\
\text { nontraditional determinants such as } \\
\text { cost factors, complementary factors of } \\
\text { production, trade deficit, they didn't } \\
\text { become more and more important } \\
\text { despite the progression in } \\
\text { globalization although showing the } \\
\text { expected correlation with FDI. }\end{array}$ \\
\hline 2008 & 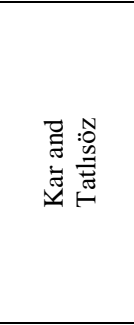 & $\begin{array}{l}\text { They used the variables } \\
\text { international net reserves, real } \\
\text { exchange rate, GDP, workday } \\
\text { losses generated from strikes, } \\
\text { openness rate, electric power } \\
\text { generation index, labor costs and } \\
\text { investment incentives for the } \\
\text { econometric analysis of the } \\
\text { determinants of FDI coming to } \\
\text { Turkey. }\end{array}$ & 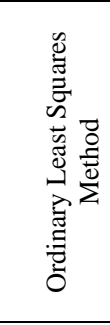 & $\begin{array}{l}\text { Data from Turkey } \\
\text { between the years } \\
\text { 1980-2003 are } \\
\text { analyzed. }\end{array}$ & $\begin{array}{l}\text { They determined that there is a } \\
\text { positive relationship between FDI and } \\
\text { international net reserves, GDP, } \\
\text { openness rate, electric power } \\
\text { generation index, and investment } \\
\text { incentives and that there is a negative } \\
\text { relationship between FDI and real } \\
\text { exchange rate and labor costs. }\end{array}$ \\
\hline 2008 & 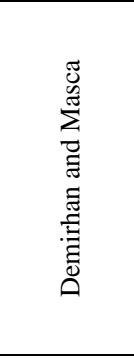 & $\begin{array}{l}\text { They took advantage of GDP } \\
\text { growth, inflation rate, } \\
\text { infrastructure expenditures, labor } \\
\text { costs, terms of trade, risk and } \\
\text { corporate income tax rates in } \\
\text { order to specify the determinants } \\
\text { of FDI. }\end{array}$ & 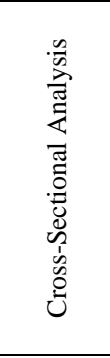 & $\begin{array}{l}\text { They examined } \\
\text { the data from } 38 \\
\text { Developing } \\
\text { Countries } \\
\text { between the years } \\
\text { 2000-2004. }\end{array}$ & $\begin{array}{l}\text { They specified a statistically } \\
\text { significant and positive relation ship } \\
\text { between FDI and GDP growth, } \\
\text { infrastructure expenditures and terms } \\
\text { of trade and they specified a negative } \\
\text { relationship between FDI and inflation } \\
\text { rate and corporate income tax rate. } \\
\text { And they also notified on the other } \\
\text { hand that labor costs have a positive } \\
\text { and risk factor has a negative sign } \\
\text { although statistically insignificant. }\end{array}$ \\
\hline 2004 & 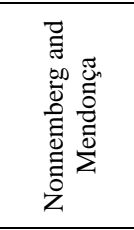 & $\begin{array}{l}\text { They used the variables GDP, } \\
\text { education level, terms of trade, } \\
\text { risk, inflation rate, stock } \\
\text { composite index, economic } \\
\text { growth and energy consumption } \\
\text { in order to specify the } \\
\text { determinants of FDI. }\end{array}$ & 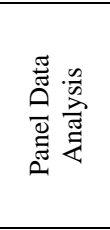 & $\begin{array}{l}\text { They examined } \\
\text { the data of } 38 \\
\text { Developing } \\
\text { Countries } \\
\text { between the years } \\
\text { 1975-2000. }\end{array}$ & $\begin{array}{l}\text { They specified that there is a } \\
\text { correlation between FDI and education } \\
\text { level, terms of trade, risk, inflation, } \\
\text { interest rate and economic growth, } \\
\text { stock composite index is closely } \\
\text { related to FDI, and GDP influences } \\
\text { FDI but not vice versa. }\end{array}$ \\
\hline
\end{tabular}




\begin{tabular}{|c|c|c|c|c|c|}
\hline 2007 & 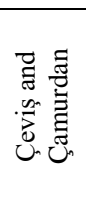 & $\begin{array}{l}\text { They used the variables GDP, } \\
\text { labor cost, terms of trade, } \\
\text { interest rate, domestic } \\
\text { investment expenditure in order } \\
\text { to specify the determinants of } \\
\text { FDI. }\end{array}$ & 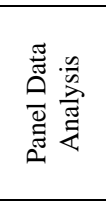 & $\begin{array}{l}\text { They examined } \\
\text { the data of } 17 \\
\text { Developing } \\
\text { Countries } \\
\text { between the years } \\
\text { 1989-2006. }\end{array}$ & $\begin{array}{l}\text { They specified that the key economic } \\
\text { determinants of FDI are inflation, } \\
\text { interest rate, terms of trade, and } \\
\text { growth rate. }\end{array}$ \\
\hline 2014 & 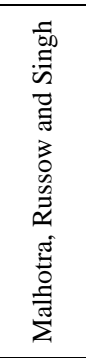 & $\begin{array}{l}\text { They used economic variables } \\
\text { such as GDP, annual change in } \\
\text { labor costs, balance of payments } \\
\text { as percentage of total exports, } \\
\text { foreign debt as percentage of } \\
\text { total exports, inflation, } \\
\text { international liquidity and } \\
\text { unemployment as well as } 10 \\
\text { different institutional variables } \\
\text { in order to specify FDI for BRIC } \\
\text { countries. }\end{array}$ & 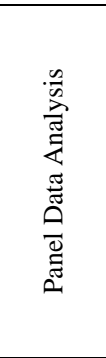 & $\begin{array}{l}\text { They analyzed } \\
\text { the data from } \\
\text { BRIC countries } \\
\text { between the years } \\
\text { 1995-2012. }\end{array}$ & $\begin{array}{l}\text { They specified that there is a strong } \\
\text { relationship between the economic and } \\
\text { non-economic institutional variables } \\
\text { and FDI and that particularly the rise } \\
\text { in GDP increases FDI. }\end{array}$ \\
\hline 2015 & 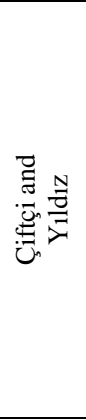 & $\begin{array}{l}\text { The variables GDP, trade } \\
\text { openness, trade deficit, exchange } \\
\text { rate, financial development and } \\
\text { foreign loan burden were } \\
\text { incorporated into the analysis for } \\
\text { analyzing the factors } \\
\text { determining the FDI coming to } \\
\text { Turkey. }\end{array}$ & 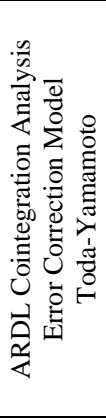 & $\begin{array}{l}\text { Data from Turkey } \\
\text { between the years } \\
\text { 1974-2012 are } \\
\text { analyzed. }\end{array}$ & $\begin{array}{l}\text { They specified that there is a } \\
\text { statistically significant and positive } \\
\text { relationship between FDI and GDP, } \\
\text { the increase in the exchange rate and } \\
\text { financial development, and on the } \\
\text { other hand there is a negative } \\
\text { relationship between FDI and the } \\
\text { increase in the trade deficit. They } \\
\text { revealed that the relationship between } \\
\text { openness (foreign trade volume) and } \\
\text { FDI is insignificant and that a foreign } \\
\text { loan burden increase causes a deterrent } \\
\text { effect for entrances of FDI. }\end{array}$ \\
\hline 2015 & 总 & $\begin{array}{l}\text { They used the variables GDP, } \\
\text { export, import, bribery and } \\
\text { corruption index, exchange rate, } \\
\text { inflation rate, interest rate, } \\
\text { infrastructure expenditure and } \\
\text { labor cost in } 6 \text { sub-sectors for the } \\
\text { analysis of the factors that } \\
\text { determine FDI. }\end{array}$ & 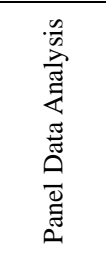 & $\begin{array}{l}\text { Data from Turkey } \\
\text { between the years } \\
\text { 1995-2012 are } \\
\text { analyzed. }\end{array}$ & $\begin{array}{l}\text { They determined that there is a } \\
\text { positive relationship between GDP, } \\
\text { export, bribery and corruption index } \\
\text { with total FDI and there is a negative } \\
\text { relationship between import, political } \\
\text { stability and infrastructure expenditure } \\
\text { and the total FDI. }\end{array}$ \\
\hline
\end{tabular}

Resource: This table is prepared by means of above mentioned resources.

Generally speaking, in the studies that were carried on through different methods of analysis, it is seen that a common conclusion was not reached from the aspects of both economic and institutional variables. To exemplify, while in many studies it is emphasized that there is a poisitive relationship between FDI and GDP growth, and labor costs, however it is seen that they were differing about infrastructure expenditures and exchange rates. It is thought that the reason of this originates from development levels of countries and unique features of the analyzed periods.

\section{Data And Methodology}

In this study, the effect of management quality of the country as well as some economic variables on the foreign direct investment to the emerging countries between the years 2002-2014 is examined. Data related to all variables other than the tax rate are obtained from The World Bank web site (http://data.worldbank.org/indicator/all). And as for the tax rate, the data about this variable are obtained from the web site of "Trading Economics" (http://www.tradingeconomics.com/). 22 countries that are enlisted in the MSCI Emerging Markets Index and 286 observations as a result which are all shown in Table 2 constitute our sample.

Table 2: Countries Examined within The Scope of the Study

\begin{tabular}{|l|l|l|l|l|}
\hline \multicolumn{1}{|c|}{ Americas } & \multicolumn{2}{|c|}{ Europe, Middle East \& Africa } & \multicolumn{2}{c|}{ Asia } \\
\hline Brazil & Czech Republic & Qatar & China & Malaysia \\
\hline Chile & Egypt & Russia & India & Philippines \\
\hline Colombia & Greece & South Africa & Indonesia & Thailand \\
\hline Mexico & Hungary & Turkey & Korea & \\
\hline Peru & Poland & United Arab Emirates & & \\
\hline
\end{tabular}

Difference Generalized Method of Moments (GMM) is implemented in our analysis. It assumed that internality problem arises because of the assumption that the rate of foreign direct investment is affected from the investment rate of the previous period, and it is also assumed that this problem can be solved through Difference GMM of Arellano and Bond (1991). Lagged value of foreign direct investment is integrated in the 
model as an independent variable. The lagged value of the foreign direct investment is used as an internal variable and the value of foreign direct investment at the time period of $\mathrm{t}-2$ is used as an instrumental variable. The models used in this study are demonstrated in the following equations:

$$
\begin{aligned}
& \mathrm{FDI}_{c, t}=a_{0}+a_{1} \mathrm{FDI}_{c, t-1}+a_{2} \mathrm{VA}_{c, t}+X_{c, t}+\varepsilon \\
& \mathrm{FDI}_{c, t}=a_{0}+a_{1} \mathrm{FDI}_{c, t-1}+a_{2} \mathrm{PS}_{c, t}+X_{c, t}+\varepsilon \\
& \mathrm{FDI}_{c, t}=a_{0}+a_{1} \mathrm{FDI}_{c, t-1}+a_{2} \mathrm{GE}_{c, t}+X_{c, t}+\varepsilon \\
& \mathrm{FDI}_{c, t}=a_{0}+a_{1} \mathrm{FDI}_{c, t-1}+a_{2} \mathrm{RQ}_{c, t}+X_{c, t}+\varepsilon \\
& \mathrm{FDI}_{c, t}=a_{0}+a_{1} \mathrm{FDI}_{c, t-1}+a_{2} \mathrm{RL}_{c, t}+X_{c, t}+\varepsilon \\
& \mathrm{FDI}_{c, t}=a_{0}+a_{1} \mathrm{FDI}_{c, t-1}+a_{2} \mathrm{CC}_{c, t}+X_{c, t}+\varepsilon \\
& \mathrm{FDI}_{c, t}=a_{0}+a_{1} \mathrm{FDI}_{c, t-1}+a_{2} \mathrm{KKM}_{c, t}+X_{c, t}+\varepsilon
\end{aligned}
$$

The dependent variable used in the model is foreign direct investment $\left(\mathrm{FDI}_{\mathrm{c}, \mathrm{f}}\right)$ and the independent variable is the lagged value of foreign direct investment $\left(\mathrm{FDI}_{\mathrm{c}, \mathrm{t}-1}\right)$. The main independent variables in the study are the variables that measure the management quality at country level. The effect of management indicators of the World Bank to the foreign direct investment is examined through using each of them in different models. VA stands for Voice and Accountability, PS for Political Stability and Absence of Voilence, GE for Governance Effectiveness, RQ for Regulatory Quality, RL for Rule of Law and CC for Control of Corruption. Other independent variables $\left(\mathrm{X}_{\mathrm{c}, \mathrm{t}}\right)$ are gross domestic product growth, tax rate, inflation rate, population rate, unemployment rate, wage rate and openness to foreign trade.

\section{Variables}

Foreign Direct Investment (FDI): It is the ratio of the investment flow that foreigner investors make in a country to the gross domestic product of that country.

Gross Domestic Product Growth (GDP Growth): It is the annual gross domestic product growth based on the currency of the related country. According to Morrissey and Rai (1995), foreign investors examine the growth expectation of a country too when they make their investment decisions. Schneider and Frey (1985), Culem (1988) and Billington (1999) are among the researchers who have explored a positive relationship between gross domestic product and foreign investment.

Corporate Income Tax Rate: According to Cassou (1997) and Kemsley (1998), if corporate income tax decreases in a country, the foreign investment to that country increases. Apart from that, there are also some studies that conclude that tax rate doesn't have an effect on foreign investment (Yulin and Rees, 1995, Porcano and Price, 1996).

Inflation Rate: It is the growth rate of the consumer price index. The related literature has generally concluded that there is a negative relationship between inflation and foreign investment. (Bengoa and Sanchez-Robles, 2003, Demirhan and Masca, 2008).

Population Growth: It is a variable measuring the population growth from the year (t-1) to t. It is supposed that there is a positive relationship between population growth which an indicator of the market size and foreign investment (Kristjánsdóttir, 2005).

Unemployment: This variable is defined as the ratio of the labor force that is unemployed but actively seeking employment and willing to work (World Bank definition). By looking at the assumption that extra foreign investment will restrict unemployment, Botric and Skuflic (2006) have found a negative relationship between unemployment and investment.

Waged and Salaried Workers: It is the proportion of the waged and salaried workers out of total employment. The wage these workers get is not affiliated to the income of their institutions (World Bank definition). Demirhan and Masca (2008) argue that there is a positive relationship between labor costs and FDI.

Trade Openness: It is defined as the ratio of terms of trade (import plus export) to the gross domestic product. Charkrabarti (2001) argues that trade openness of a country is an important factor in the investment decision. Generally a positive relationship is expected between terms of trade and foreign investment (Edwards, 1990).

KKM variables: Management quality at the country level is measured with 6 management indicators of the World Bank which are named as KKM variables by Kaufmann, Kraay and Mastruzzi (2007) These variables are voice and accountability (VA), political stability and absence of violence (PS), governance effectiveness (GE), regulatory quality (RQ), rule of law (RL) and control of corruption (CC). Kaufmann, Kraay and Mastruzzi (2007) have defined these variables as follows: "Voice and accountability is measured by the ability of the citizens of a country to get involved with choosing the government, freedom of expression, freedom of organization, and freedom of press. Political stability and absence of violence measure the likelihood of subversion of the government with terror, unconstitutional incidents or local violence. Governance effectiveness measures the quality of public service, the quality of government services and inconnection of these services with political oppression, the quality of establishing and implementing a policy and commitment of the country 
to these policies. Regulatory Quality measures the ability of the government to establish and implement policies and regulations that support the private sector and let it improve. Rule of law measures the observance of the law, fulfillment quality of undertakings, quality of police department and courts as well as the likelihood of crimes and violence. Control of corruption measures the level of exploitation of public power which includes both insignificant and most significant levels of corruption. It also includes elites seizing the state and using it for private benefits."

\section{Empirical Results}

The descriptive statistics of the dependent and independent variables that are used in this study are shown in Table 3. It is seen that in emerging countries foreign direct investment flow of $3.24 \%$ took place on average. Annual gross domestic product growth rate is $4.65 \%$ on average. The inflation is $4.99 \%$, average population growth rate is $1.64 \%$, unemployment rate is $7.99 \%$, corporate income tax is $27.98 \%$, wage labor rate is $67.35 \%$, and openness to foreign trade is $0.74 \%$ of the gross domestic product. The descriptive statistics of the independent variables that measure the management quality of the countries that are examined in this study also take place in Table 3. Voice and accountability (VA), political stability and absence of violence (PS), governance effectiveness (GE), regulatory quality (RQ), rule of law (RL), control of corruption (CC) and KKM variable which is the the average of the mentioned 6 variables all range between $(-2.5)$ and $(+2.5)$. $(-2.5)$ represents the lowest and $(+2.5)$ represents the highest quality of management. The more value these variables take the more the quality of country management is. According to Table 1, the variables measuring the quality of country management are below 1 on average. And this shows that emerging countries have a low-quality management on average. It is seen that the variable political stability and absence of violence has the lowest value on average.

Table 3: Descriptive Statistics

\begin{tabular}{|l|l|l|l|l|l|l|}
\hline \multicolumn{1}{|c|}{ Variables } & \multicolumn{1}{c|}{$\mathbf{N}$} & \multicolumn{1}{c|}{ Mean } & Std. Dev. & \multicolumn{1}{c|}{ p25 } & \multicolumn{1}{c|}{ p50 } & \multicolumn{1}{c|}{ p75 } \\
\hline FDI & 286 & 3.24 & 4.63 & 1.47 & 2.61 & 4.01 \\
\hline GDPG & 286 & 4.65 & 3.96 & 2.83 & 4.73 & 6.44 \\
\hline INFLATION & 273 & 4.99 & 4.37 & 2.62 & 4.10 & 6.39 \\
\hline POPULATION & 286 & 1.64 & 2.83 & 0.41 & 1.22 & 1.51 \\
\hline UNEMPLOYMENT & 260 & 7.99 & 5.59 & 4.05 & 7.1 & 9.9 \\
\hline TAX & 276 & 27.98 & 8.25 & 20 & 28 & 33 \\
\hline TRADE & 264 & 0.74 & 0.41 & 0.48 & 0.58 & 0.88 \\
\hline WAGE & 234 & 67.35 & 17.72 & 54.5 & 66.25 & 82.3 \\
\hline VA & 286 & 0.04 & 0.75 & -0.49 & 0.06 & 0.68 \\
\hline PS & 286 & -0.25 & 0.89 & -0.95 & -0.28 & 0.53 \\
\hline GE & 286 & 0.34 & 0.54 & -0.09 & 0.31 & 0.82 \\
\hline RQ & 286 & 0.37 & 0.54 & -0.09 & 0.37 & 0.78 \\
\hline RL & 286 & 0.12 & 0.63 & -0.45 & 0.08 & 0.66 \\
\hline CC & 286 & 0.02 & 0.63 & -0.44 & -0.11 & 0.39 \\
\hline KKM & 286 & 0.11 & 0.57 & -0.37 & -0.02 & 0.62 \\
\hline
\end{tabular}

In Table 4, each variable of management quality is split into 4 different quarters. The first quarter shows the lowest and the 4th quarters shows the highest quality of management. Foreşgn direct investments in each quarter are examined. The expectation is that investment rate will increase when approaching to the fourth quarter. According to Table 4, the highest level of investment takes place in the 4th quarter for all variables. Foreign investment is increased when approaching to the 4th quarter for RQ, RL, CC and KKM as expected. And as for variables VA, PS and GE, although the investment rate is higher than of the 1st quarter, a linear increase is not observed between the quarters.

Table 4: The Relation Between Foreign Direct Investment and the Quality of Management

\begin{tabular}{|l|l|}
\hline VA & FDI \\
\hline 1st Quarter & 3.23 \\
\hline 2nd Quarter & 2.55 \\
\hline 3rd Quarter & 2.43 \\
\hline 4th Quarter & 4.75 \\
\hline
\end{tabular}

\begin{tabular}{|l|l|}
\hline PS & FDI \\
\hline 1st Quarter & 2.28 \\
\hline 2nd Quarter & 3.07 \\
\hline 3rd Quarter & 2.55 \\
\hline 4th Quarter & 5.07 \\
\hline
\end{tabular}




\begin{tabular}{|l|l|}
\hline GE & FDI \\
\hline 1st Quarter & 2.93 \\
\hline 2nd Quarter & 2.48 \\
\hline 3rd Quarter & 3.70 \\
\hline 4th Quarter & 3.88 \\
\hline
\end{tabular}

\begin{tabular}{|c|c|}
\hline RQ & FDI \\
\hline 1st Quarter & 2.46 \\
\hline 2nd Quarter & 2.71 \\
\hline 3rd Quarter & 3.07 \\
\hline 4th Quarter & 4.77 \\
\hline RL & FDI \\
\hline 1st Quarter & 2.72 \\
\hline 2nd Quarter & 2.76 \\
\hline 3rd Quarter & 2.86 \\
\hline 4th Quarter & 4.64 \\
\hline
\end{tabular}

\begin{tabular}{|l|l|}
\hline CC & FDI \\
\hline 1st Quarter & 2.49 \\
\hline 2nd Quarter & 2.77 \\
\hline 3rd Quarter & 3.32 \\
\hline 4th Quarter & 4.41 \\
\hline
\end{tabular}

\begin{tabular}{|l|l|}
\hline KKM & FDI \\
\hline 1st Quarter & 2.67 \\
\hline 2nd Quarter & 2.74 \\
\hline 3rd Quarter & 2.93 \\
\hline 4th Quarter & 4.64 \\
\hline
\end{tabular}

Pearson correlation coefficients for dependent and independent variables that are used in this study are shown in Table 5. There is a positive relationship between gross domestic product growth, population rate, terms of trade, wage labor rate and all management quality variables and foreign direct investment according to this table. On the contrary, inflation, unemployment and tax rate have a negative relationship with foreign investment. A remarkable correlation is not observed between the variables used in the same regression.

Table 5: Pearson Correlation Coefficient

\begin{tabular}{|l|l|l|l|l|l|l|l|}
\hline \multicolumn{1}{|c|}{ Variables } & \multicolumn{1}{|c|}{ FDI } & GDPG & INFLATION & POPULATION & UNEMP. & TAX & TRADE \\
\hline FDI & 1 & & & & & \\
\hline GDPG & 0.0489 & 1 & & & & \\
\hline INFLATION & -0.0210 & 0.1062 & 1 & & & \\
\hline POPULATION & 0.0296 & 0.4127 & 0.1315 & 1 & & \\
\hline UNEMPLOYMENT & -0.0950 & -0.3217 & 0.0928 & -0.2112 & 1 & & \\
\hline TAX & -0.1189 & 0.1423 & 0.1229 & 0.4116 & & \\
\hline TRADE & 0.2042 & -0.1143 & -0.2697 & -0.1319 & 0.0963 & 1 & \\
\hline WAGE & 0.1570 & 0.0072 & -0.0592 & 0.2290 & -0.2923 & -0.3864 & 1 \\
\hline VA & 0.0923 & -0.3612 & -0.2051 & -0.3481 & 0.0200 & -0.2834 & 0.3102 \\
\hline PS & 0.1740 & -0.0250 & -0.2945 & 0.2586 & 0.3049 & -0.2364 & 0.1238 \\
\hline GE & 0.1214 & -0.0938 & -0.3691 & 0.1335 & -0.0635 & -0.1534 & 0.4752 \\
\hline RQ & 0.2369 & -0.2191 & -0.3561 & -0.0060 & -0.0949 & -0.1126 & 0.6125 \\
\hline RL & 0.1673 & -0.0910 & -0.2880 & 0.1377 & -0.0325 & -0.2602 & 0.4525 \\
\hline CC & 0.1854 & 0.0422 & -0.3134 & 0.3882 & -0.0251 & -0.2623 & 0.4997 \\
\hline KKM & 0.1882 & -0.1455 & -0.3413 & 0.1077 & -0.0143 & -0.0373 & 0.3423 \\
\hline
\end{tabular}

\begin{tabular}{|l|l|l|l|l|l|l|l|l|}
\hline Variables & Wage & \multicolumn{1}{|c|}{ VA } & PS & GE & RQ & RL & CC & KKM \\
\hline Wage & 1 & & & & & & & \\
\hline VA & 0.0330 & 1 & & & & & & \\
\hline PS & 0.6429 & 0.3546 & 1 & & & & & \\
\hline GE & 0.4434 & 0.3997 & 0.7826 & 1 & & & & \\
\hline RQ & 0.4016 & 0.6299 & 0.7513 & 0.8493 & 1 & & & \\
\hline RL & 0.4249 & 0.5003 & 0.8238 & 0.8868 & 0.8277 & 1 & & \\
\hline CC & 0.4372 & 0.3410 & 0.7876 & 0.8318 & 0.8143 & 0.8491 & 1 & \\
\hline KKM & 0.4585 & 0.6336 & 0.8813 & 0.9044 & 0.9335 & 0.9403 & 0.8846 & 1 \\
\hline
\end{tabular}

GMM regression results are given for each model in Table 6. VA is used as a management quality variable in the first column. According to the results, there is a positive relationship between VA and foreign direct investment. Thus, in emerging countries, if political stability and absence of violence increases, foreign 
investments will also increase. In the 2nd and 3rd columns, PS and GE variables are used respectively as management quality variables. Any effect of the either columns on foreign investment has not been found. The variables RQ and RL have been used as the management quality variables in the 4th and 5th columns and a positive relationship is explored between these variables and foreign investment. In the 6th and 7th columns, the relationship between the variables CC and KKM and foreign investment is tested and it is again concluded that these variables positively affect foreign investment. Despite the fact that any effect of PS and GE is not found on foreign investment, since KKM which is the average of all variables is positive, it is concluded that the higher the management quality is the bigger foreign investment to those countries will be.

Considering other independent variables used in the study, a positive coefficient is found for the lagged value of foreign direct investment. In other words, foreign direct invesment of the previous period plays a positive role in the decision processes of investors. In the second place, a positive relation is explored between gross domestic product and foreign direct investment. If the gross domestic product of a country is big, then the foreign direct investment made to that country will also be big. It is also concluded that the population rate and unemployment rate affect foreign investment rate in a negative way.

Table 6: Regression Results

\begin{tabular}{|c|c|c|c|c|c|c|c|}
\hline & FDI & FDI & FDI & FDI & FDI & FDI & FDI \\
\hline VA & $\begin{array}{l}13.639 * * \\
{[0.044]}\end{array}$ & & & & & & \\
\hline PS & & $\begin{array}{l}0.586 \\
{[0.874]}\end{array}$ & & & & & \\
\hline GE & & & $\begin{array}{l}-4.619 \\
{[0.594]}\end{array}$ & & & & \\
\hline RQ & & & & $\begin{array}{l}23.176 \text { *** } \\
{[0.001]}\end{array}$ & & & \\
\hline RL & & & & & $\begin{array}{l}16.124 * * \\
{[0.014]}\end{array}$ & & \\
\hline $\mathrm{CC}$ & & & & & & $\begin{array}{l}15.319^{* *} \\
{[0.016]}\end{array}$ & \\
\hline KKM & & & & & & & $\begin{array}{l}16.944 * * \\
{[0.038]}\end{array}$ \\
\hline FDI $_{t-1}$ & $\begin{array}{l}0.378 * * * \\
{[0.000]}\end{array}$ & $\begin{array}{l}0.414 * * * \\
{[0.000]}\end{array}$ & $\begin{array}{l}0.422 * * * \\
{[0.000]}\end{array}$ & $\begin{array}{l}0.358 * * * \\
{[0.000]}\end{array}$ & $\begin{array}{l}0.354 * * * \\
{[0.000]}\end{array}$ & $\begin{array}{l}0.402 * * * \\
{[0.000]}\end{array}$ & $\begin{array}{l}0.377 * * * \\
{[0.000]}\end{array}$ \\
\hline GDPG & $\begin{array}{l}0.999 * * * \\
{[0.007]}\end{array}$ & $\begin{array}{l}0.765 * * \\
{[0.026]}\end{array}$ & $\begin{array}{l}0.784 * * \\
{[0.020]}\end{array}$ & $\begin{array}{l}0.987 * * * \\
{[0.008]} \\
\end{array}$ & $\begin{array}{l}0.879 * * \\
{[0.012]}\end{array}$ & $\begin{array}{l}0.800 * * \\
{[0.024]}\end{array}$ & $\begin{array}{l}0.822 * * \\
{[0.020]}\end{array}$ \\
\hline TAX & $\begin{array}{l}-0.187 \\
{[0.586]}\end{array}$ & $\begin{array}{l}-0.212 \\
{[0.518]}\end{array}$ & $\begin{array}{l}-0.190 \\
{[0.562]}\end{array}$ & $\begin{array}{l}-0.158 \\
{[0.656]}\end{array}$ & $\begin{array}{l}-0.297 \\
{[0.379]}\end{array}$ & $\begin{array}{l}-0.545 \\
{[0.140]}\end{array}$ & $\begin{array}{l}-0.287 \\
{[0.402]}\end{array}$ \\
\hline INFLATION & $\begin{array}{l}0.208 \\
{[0.647]}\end{array}$ & $\begin{array}{l}0.276 \\
{[0.523]}\end{array}$ & $\begin{array}{l}0.338 \\
{[0.447]}\end{array}$ & $\begin{array}{l}0.024 \\
{[0.960]}\end{array}$ & $\begin{array}{l}0.020 \\
{[0.965]}\end{array}$ & $\begin{array}{l}0.116 \\
{[0.800]}\end{array}$ & $\begin{array}{l}0.119 \\
{[0.794]}\end{array}$ \\
\hline POPULATION & $\begin{array}{l}-4.341 * * \\
{[0.050]}\end{array}$ & $\begin{array}{l}-3.390 \\
{[0.101]}\end{array}$ & $\begin{array}{l}-3.844 * \\
{[0.084]}\end{array}$ & $\begin{array}{l}-2.110 \\
{[0.352]}\end{array}$ & $\begin{array}{l}-2.916 \\
{[0.170]}\end{array}$ & $\begin{array}{l}-3.503 \\
{[0.105]}\end{array}$ & $\begin{array}{l}-3.100 \\
{[0.149]}\end{array}$ \\
\hline UNEMPLOYMENT & $\begin{array}{l}-0.642 * \\
{[0.095]}\end{array}$ & $\begin{array}{l}-0.875^{* *} \\
{[0.024]}\end{array}$ & $\begin{array}{l}-0.979 \text { *** } \\
{[0.009]}\end{array}$ & $\begin{array}{l}-0.622 \\
{[0.106]}\end{array}$ & $\begin{array}{l}-0.418 \\
{[0.304]}\end{array}$ & $\begin{array}{l}-0.629 * \\
{[0.097]}\end{array}$ & $\begin{array}{l}-0.500 \\
{[0.221]}\end{array}$ \\
\hline WAGE & $\begin{array}{l}0.041 \\
{[0.930]}\end{array}$ & $\begin{array}{l}0.117 \\
{[0.794]}\end{array}$ & $\begin{array}{l}0.100 \\
{[0.822]}\end{array}$ & $\begin{array}{l}0.262 \\
{[0.588]}\end{array}$ & $\begin{array}{l}0.074 \\
{[0.871]}\end{array}$ & $\begin{array}{l}0.185 \\
{[0.691]}\end{array}$ & $\begin{array}{l}0.106 \\
{[0.819]}\end{array}$ \\
\hline TRADE & $\begin{array}{l}-9.268 \\
{[0.369]}\end{array}$ & $\begin{array}{l}-7.233 \\
{[0.482]}\end{array}$ & $\begin{array}{l}-5.949 \\
{[0.545]}\end{array}$ & $\begin{array}{l}-7.959 \\
{[0.452]}\end{array}$ & $\begin{array}{l}-14.710 \\
{[0.163]}\end{array}$ & $\begin{array}{l}-1.135 \\
{[0.914]}\end{array}$ & $\begin{array}{l}-10.655 \\
{[0.303]}\end{array}$ \\
\hline $\mathbf{N}$ & 178 & 178 & 178 & 178 & 178 & 178 & 178 \\
\hline
\end{tabular}

Note: $* * *, * *$ and $*$ indicate significant at $1 \%, 5 \%$ and $10 \%$ levels respectively.

\section{Conclusion}

The mission of a contemporary finance manager, based on the improvements in the finance function, is to maximize the firm value and the prosperity of the shareholders. All the same, the goal of the countries that want to export knowledge, technology and export of funds through FDI is to maintain the profit maximization. In general, when considered emerging countries take the lion's share, the emerging countries have to maintain certain functions in order to become capable of competing. Institutional variables such as political stability of the investee country, legal arrangements and the steps in the fight against corruption together reveal the quality of management. The expectations that maintaining the mentioned sufficiencies and improvements in the economic variables will increase the FDI rates of emerging countries have formed a basis for the studies carried out in the finance literature.

In this study, the determinants of foreign direct investment rate to emerging countries between the years 2002-2014 are examined. Implementing GMM method, it is concluded that the management quality at the country level has a positive effect on FDI. Among management quality variables, significant relationships have been explored for Voice and Accountability (VA), Regulatory Quality (RQ), Rule of Law (RL) and Control of 
Corruption (CC). It is concluded that among economic variables, the lagged value of FDI and gross domestic product growth affects FDI in a positive way and population and unemployment rates in a negative way. The findings show that countries that seek for a bigger share of the FDI stock in the globalizing world have to take the variables of management quality into consideration and that the development speed of macroeconomic variables has to be kept at a sustainable point.

\section{References}

[1]. H.G. Jeong, The Determinants of Foreign Direct Investment in the Business Services Industry. International Economic Journal, 28(3), 2014, 475-495.

[2]. M. Kar and F. Tatlisöz, Econometric Analysis Of Determinants of Foreign Direct Investment in Turkey. KMU Faculty of Economics and Administrative Sciences Journal, 10(14), 2008, 436-458.

[3]. B. Özcan and A. Arı, Doğrudan Yabancı Yatırımların Belirleyicileri Üzerine Bir Analiz: OECD Örneği. İstanbul University Economics Faculty Econometrics and Statistics Journal, 12, 2010, 65-88.

[4]. D.M. Bekana, Determinants of Foreign Direct Investment in Ethiopia; Time Series Evidence From 1991-2013. The Journal of Developing Areas, 50(1), 2016, 141-155.

[5]. S.G. Özçalık and G.G. Gibson, Factors Affect Flow of Foreign Direct Investment (A Case Study of South Africa:1970-2014). Research Journal of Finance and Accounting, 7(16), 2016, 58-65.

[6]. D.K. Malhotra, L. Russow and R. Singh, Determinants of Foreign Direct Investment in Brazil, Russia, India, and China. International Journal of Business, Accounting, and Finance, 8(1), 2014, 130-148.

[7]. Foundation for Political, Economic and Social Research (SETA), Türkiye'de Doğrudan Yabancı Yatırımlar. 33, 1-29, 2011.

[8]. B. Ohlin, Comercio Interregional e Internacional. Oikos, Barcelona, 1971 (orig. 1933).

[9]. S. Mahalakshmi, S. Thiyagarajan and G. Naresh, Determinants of Foreign Direct Investment Inflows into India. Journal of International Economics, 6(1), 2015, 24-43.

[10]. M.B. Nonnemberg and M.J.C. De Mendonça, The Determinants of Foreign Direct Investment in Developing Countries. http://www.anpec.org.br/encontro2004/artigos/A04A061.pdf, 2004, Access Date: 01.06.2016.

[11]. J. Huang, X. Chen, B. Huang and X. Yang, Economic and Environmental Impacts of Foreign Direct Investment in China: A Spatial Spillover Analysis. China Economic Review, 2016, Article In Press.

[12]. T.S. Yean, T. Yen Nee and A.K. Jia Yi, Outward Foreign Direct Investment from Malaysia. Journal of Southeast Asian Economies, 32(3), 2015, 358-374.

[13]. J.C. Botello and M. Davilla, The New Determinant Creation Theory: A Way to Attract New Foreign Direct Investment Flows International Journal of Business and Economic Development, 3(1), 2015, 96-109.

[14]. A.A. Bevan and S. Estrin, The Determinants of Foreign Direct Investment into European Transition Economies. Journal of Comparative Economic, 32, 2004, 775-787.

[15]. S. Artan and P. Hayaloğlu, Institutional Determinants of Foreign Direct Investment: Evidence from OECD Countries. Ege Akademik Bakış, 15(4), 2015, 551-564.

[16]. P. Nunnenkamp, Determinants of FDI in Developing Countries: Has Globalization Changed the Rules of the Game. Kiel Working Paper. 1122, 1-44, 2002.

[17]. E. Demirhan and M. Masca, The Economic Determinants of Foreign Direct Investment in Developing Countries and Transition Economies. The Pakistan Development Review, 46(3), 2008, 285-299.

[18]. İ. Çeviş and B. Çamurdan, The Economical Determinants of Foreign Direct Investment (FDI) in Developing Countries and Transition Economies. E-Journal of New World Sciences Academy, 4(3), 2007, 210-223.

[19]. F. Çiftçi and R. Yıldız, The Economic Determinants of Foreign Direct Investment: A Time Series Analysis on the Turkish Economy. Business and Economics Research Journal, 6(4), 2015, 71-95.

[20]. E. Öğrül and M. Eryiğit, The Factors that Affect on Foreign Direct Investments in Turkey (sectoral comparisons). Theoretical and Applied Economics, 22(3), 2015, 251-272.

[21]. M. Arellano and S. Bond, Some Tests of Specification for Panel Data. Monte Carlo Evidence and an Application to Employment Equations. Review Economic Studies, 58, 1991, 277-297.

[22]. O. Morrissey and Y. Rai, The GATT Agreement on Trade Related Investment Measures: Implications for Developing Countries and their Relationship with Transnational Corporations. Journal of Development Studies, 31(5), 1995, 702-724.

[23]. F. Schneider and B. Frey, Economic and Political Determinants of Foreign Direct Investment. World Development, 13(2), 1985, 161-175.

[24]. C.G. Culem, The Locational Determinants of Direct Investments Among Industrialized Countries. European Economic Review, 32, 1998, 885-904.

[25]. N. Billington, The Location of Foreign Direct Investment: An Empirical Analysis. Applied Economics, 31, 1999, 65-76.

[26]. S.P. Cassou, The Link Between Tax Rates and Foreign Direct Investment. Applied Economics, 29, 1997, 1295-1301.

[27]. D. Kemsley, The Effect of Taxes on Production Location. Journal of Accounting Research, 36, 1998, $321-341$.

[28]. N. Yulin and M.R. Reed, Locational Determinants of U. S. Direct Foreign Investment in Food and Kindered Products Agrobusiness, 11, 1995, 77-86.

[29]. T.M. Porcano and C.E. Price, The Effects of Government Tax and Non-tax Incentives on Foreign Direct Investment. Multinational Business Review, 4, 1996, 9-20.

[30]. M. Bengoa and B. Sanchez-Robles, Foreign Direct Investment, Economic Freedom and Growth: New Evidence from Latin America. Eur. J. Polit. Eco, 19, 2003, 529-545.

[31]. H. Kristjánsdóttir, Determinants of Foreign Direct Investment in Iceland. Centre for Applied Microeconometrics. Department of Economics, University of Copenhagen, 2005

[32]. V. Botric and L. Skuflic, Main Determinants of Foreign Direct Investment in the Southeast European Countries. Transition Studies Review, 13 (2), 2006, 359-377.

[33]. A. Charkrabarti, The Determinants of Foreign Direct Investment: Sensitivity Analyses of Cross-Country Regressions. Kyklos, 54(1), 2001, 89-114

[34]. S. Edwards, Capital Flows, Foreign Direct Investment, and Debt-Equity Swaps in Developing Countries. National Bureau of Economic Research (Cambridge, M. A.), Working Paper No. 3497, 1990.

[35]. D. Kaufmann, A. Kraay and M. Mastruzzi, Governance Matters VI: Aggregate and Individual Governance Indicators $1996-2006$. World Bank Policy Research, Working Paper. No 4280, 2007. 